\title{
ERRATUM
}

\section{Management of neglected sacral fracture with cauda equina syndrome: report of two cases with review of literature}

R Mahajan, V Tandon, K Das, A Nanda, R Venkatesh and HS Chhabra

Spinal Cord Series and Cases (2016) 2, 15028; doi:10.1038/scsandc.2015.28; published online 7 January 2016

Correction to: Spinal Cord Series and Cases (2015) 2, 15020. doi:10.1038/scsandc.2015.20; published online 8 October 2015

Since the publication of this article, the authors have noticed an error in the author R Mahajan's name in the article PDF. This has now been rectified and the corrected article appears online together with this erratum.

The publisher apologises for any inconvenience caused. 